\title{
EFEKTIVITAS PENAGIHAN PAJAK DENGAN SURAT \\ TEGURAN, SURAT PAKSA, DAN PENYITAAN DAN \\ KONTRIBUSINYA TERHADAP PENERIMAAN PAJAK DI \\ KPP PRATAMA SEMARANG TENGAH SATU
}

\author{
Nirsetyo Wahdi \\ Fakultas Ekonomi, Universitas Semarang, \\ nswahdi.feusm@gmail.com \\ Ratna Wijayanti \\ Fakultas Ekonomi, Universitas Semarang \\ Danang \\ Fakultas Ekonomi, Universitas Semarang
}

\begin{abstract}
ABSTRAK
Berdasarkan Undang-Undang Nomor 19 Tahun 2000 tentang Penagihan Pajak dengan Surat Paksa, utang pajak merupakan dasar penagihan pajak. Dengan penagihan pajak, khususnya penagihan pajak aktif, diharapkan Wajib Pajak atau Penanggung Pajak membayar utang pajaknya. Tujuan dari penelitian ini adalah untuk menentukan efektivitas penagihan pajak aktif melalui Surat Teguran, Surat Paksa, dan Surat Perintah Melaksanakan Penyitaan dan kontribusinya terhadap optimalisasi penerimaan pajak di KPP Pratama Semarang Tengah Satu. Hasil analisis data menunjukkan bahwa efektivitas penagihan pajak melalui Surat Teguran tidak efektif, melalui Surat Paksa tidak efektif, dan melalui Penyitaan kurang efektif. Kontribusi penerimaan penagihan pajak melalui Surat Teguran, Surat Paksa, dan Penyitaan terhadap penerimaan pajak KPP Pratama Semarang Tengah Satu tergolong sangat kurang. Penelitian ini juga bertujuan mendeskripsikan hambatan yang dihadapi oleh Seksi Penagihan dalam melakukan penagihan pajak dan solusi yang telah dilakukan dalam menghadapi hambatan/kendala tersebut.
\end{abstract}

Kata kunci: Efektivitas, Kontribusi, Surat Teguran, Surat Paksa, Surat Perintah Melaksanakan Penyitaan 
Dinamika Sosial Budaya, Vol 20, No. 2, Desember 2018, pp 106-119

p-ISSN: 1410-9859\& e-ISSN: 2580-8524

http://journals.usm.ac.id/index.php/jdsb

PENDAHULUAN

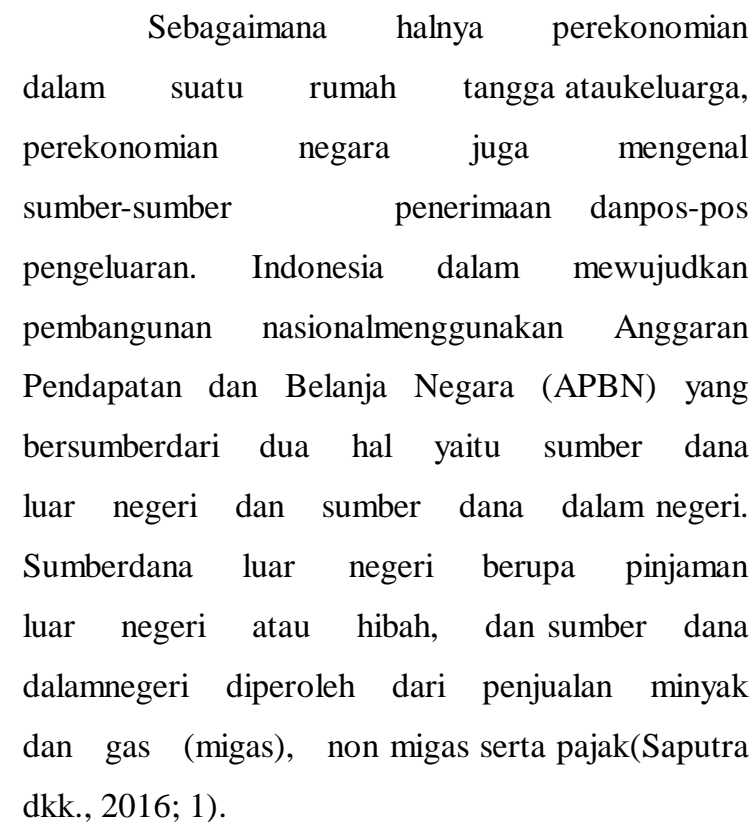

$\begin{array}{rrr}\text { Seiring } & \text { dengan } & \text { meningkatnya } \\ \text { tuntutan } & \text { pemenuhan } & \text { pendanaan }\end{array}$

pembangunan nasional yang berasal dari sumber penerimaan dalam negeri, pajak memegang peranan dan fungsi yang sangat strategis. Tanpa pajak, sebagian besar kegiatan negara sulit untuk dapat dilaksanakan. Penggunaan uang pajak meliputi mulai dari belanja pegawai sampai dengan pembiayaan berbagai proyek pembangunan.Pajak juga digunakan untuk mensubsidi barang-barang yang sangat dibutuhkan masyarakat serta membantu UMKM baik dalam hal pembinaan dan modal.Pencapaian target penerimaan pajak merupakan ukuran kuantitatif kinerja Direktorat Jenderal Pajak yang harus diamankan dengan baik. Pemerintah dalam hal ini Direktorat Jenderal Pajak, sesuai dengan fungsinya berkewajiban melakukan pembinaan/penyuluhan, pelayanan, dan pengawasan dalam rangka mengoptimalkan penerimaan pajak. Sesuai dengan Rencana Strategis Direktorat Jenderal Pajak tahun 2015-2019, tujuan yang ingin dicapai adalah optimalisasi penerimaan negara.
Kondisi yang diinginkan dalam Rencana Strategis tersebut adalah penerimaan pajak optimal. Dalam Rencana Strategis DJP, telah dituangkan Destination Statement DJP bahwa Tax Ratio yang ingin dicapai pada tahun 2019adalah sebesar 15\%. Namun faktanya, Tax Ratio Indonesia saat ini adalah sebesar $10,3 \%$.

Untuk mencapai penerimaan pajak yang optimalsasaran strategis yang ingin dicapai oleh DJP adalah kepatuhan Wajib Pajak yang tinggi. Kepatuhan pajak menjadi salah satu bagian dari Key Performance

Indicator (KPI) yang harus dicapai dan selalu dievaluasi oleh Direktorat Jenderal Pajak karena penerimaan pajak sangat dipengaruhi oleh kepatuhan Wajib Pajak dalam melaporkan dan menyetorkan pajak. Ukuran kepatuhan yang digunakan saat ini adalah kepatuhan formal saja, yaitu kepatuhan pelaporan/penyampaian SPT. Rasio kepatuhan penyampaian SPT Kanwil DJP Jawa Tengah I di tahun 2017 mencapai $89,80 \%$ atau meningkat $33,49 \%$ dari tahun 2016 yakni sebesar 67,27\%. Realisasi penyampaian SPT di Kanwil DJP Jawa Tengah I mencapai 689.387 dari 767.708 Wajib Pajak terdaftar yang wajib SPT.

Namun demikian, tingkat penyampaian SPT yang tinggi tidak berbanding lurus dengan jumlah penerimaan pajak yang tinggi juga. Dari total 1.646.583 Wajib Pajak yang terdaftar di Kanwil DJP Jawa Tengah I, hanya 67.765 Wajib Pajak yang melaporkan SPT dan melakukan pembayaran pajak. Penerimaan pajak Kanwil DJP Jawa Tengah di tahun 2017 adalah sebesar Rp2 5.546.060.761.155 atau mencapai $82,33 \%$ dari total target penerimaan yakni sebesar Rp31.029.877.358.000. Penerimaan ini turun sebesar $14,38 \%$ dari 
Dinamika Sosial Budaya, Vol 20, No. 2, Desember 2018, pp 106-119

p-ISSN: 1410-9859\& e-ISSN: 2580-8524

http://journals.usm.ac.id/index.php/jdsb

penerimaan di tahun 2016 sebesar Rp29.838.202.458.136. Hal ini dimungkinkan karena Wajib Pajak selama ini hanya patuh secara formal (tepat waktu pelaporan dan pembayaran) namun belum patuh secara material (kebenaran pelaporan dan pembayaran)

$\begin{array}{rrrr}\text { Wajib Pajak tersebut } & \text { selanjutnya } \\ \text { perlu dibangun dan dibina kepatuhannya }\end{array}$ dengan menggunakan fungsi-fungsi yang dimiliki oleh DJP, yaitu pelayanan, penyuluhan, pengawasan, pemeriksaan, dan penegakan hukum agar menjadi Wajib Pajak yang patuh baik secara formal maupun material.Wajib Pajak yang sudah patuh, maka kepadanya cukup diberikan pelayanan yang baik agar dapat menghitung, melapor, dan membayar pajak dengan mudah, murah dan cepat.Wajib Pajak yang cukup patuh maka fungsi yang perlu diterapkan adalah pengawasan. Wajib Pajak yang kurang patuh, maka tindakan yang perlu diterapkan adalah pemeriksaan. Sedangkan bagi Wajib Pajak yang tidak patuh atau diduga melakukan tindakan pidana perpajakan, maka fungsi yang perlu diterapkan adalah penegakan hokum.

Tujuan pemeriksaan pajak adalah untuk menguji kepatuhan Wajib Pajak serta untuk tujuan lain dalam rangka melaksanakan ketentuan peraturan perundang- undangan perpajakan. Menurut Anggraini (2016; 2), pemeriksaan pajak sebagai penguji kepatuhan Wajib Pajak merupakan keharusan. Fiskus melakukan pemeriksaan pajak dari tahun ke tahun secara berkesinambungan sebagai perwujudan bentuk pengawasan dan pembinaan kepada Wajib Pajak dalam pelaksanaan pemungutan pajak di Indonesia.

Direktorat Jenderal Pajak, melalui Kantor Pelayanan Pajak (KPP), ditunjuk oleh negara sebagai penegak hukum untuk memaksa Wajib Pajak agar kepatuhan pajak tercapai dengan melaksanakan tindakan penagihan pajak. Penagihan pajak adalah serangkaian tindakan agar Penanggung Pajak melunasi utang pajak dan biaya penagihan pajak dengan menegur atau mengingatkan, melaksanakan penagihan seketika dan sekaligus, memberitahukan Surat Paksa, mengusulkan pencegahan, melaksanakan penyitaan, melaksanakan penyanderaan, serta menjual barang yang telah disita. Penjualan barang yang telah disita biasanya dilakukan melalui pelelangan kecuali untuk aset-aset tertentu seperti surat berharga, piutang, dan penyertaan modal pada perusahaan lain.

\section{TUJUAN PENELITIAN}

Proses sita hingga lelang tersebut merupakan bagian dari upaya penagihan pajak yang hingga kini belum dilunasi utang pajaknya oleh wajib pajak yang bersangkutan. Tindakan sita dan lelang harta penunggak pajak tersebut dilakukan karena upaya penagihan aktif lainnya tidak dapat membuat penunggak pajak melunasi utang pajaknya. Dengan adanya tindakan penagihan pajak berupa penerbitan surat teguran, surat paksa, hingga berupa sita dan lelang tersebut, diharapkan agar Wajib Pajak atau Penanggung Pajak melunasi utang pajaknya sehingga optimalisasi penerimaan pajak dapat tercapai.

Tujuan penelitian ini untuk menganalisis efektivitas penagihan pajak, dan kendala serta bagaimana cara mengatasi kendala yang timbul dalam pelaksanaan Penagihan Pajak dengan Surat Teguran, Surat Paksa, dan Penyitaan di Kantor Pelayanan Pajak Pratama Semarang Tengah 
Dinamika Sosial Budaya, Vol 20, No. 2, Desember 2018, pp 106-119

p-ISSN: 1410-9859\& e-ISSN: 2580-8524

http://journals.usm.ac.id/index.php/jdsb

Satu. Dan seberapa besar kontribusi penerimaan pajak melalui tindakan penagihan pajak dengan Surat Teguran, Surat Paksa, dan Penyitaan terhadap penerimaan pajak di Kantor Pelayanan Pajak Pratama Semarang Tengah Satu.

\section{TINJAUAN PUSTAKA}

\section{Pajak}

Definisi atau pengertian pajak menurut Prof. Dr. Rochmat Soemitro, S.H.(dalam Mardiasmo, 2009): "Pajak adalah iuran rakyat kepada kas negara berdasarkan undang-undang (yang dapat dipaksakan) dengan tiada mendapat jasa timbal (kontraprestasi) yang langsung dapat ditunjukkan dan yang digunakan untuk membayar pengeluaran umum." Sedangkan definisi pajak menurut Undang- Undang Nomor 6 Tahun 1983 Tentang Ketentuan Umum Dan Tata Cara Perpajakan (KUP) sebagaimana telah diubah terakhir dengan UndangUndang Nomor 16

Tahun 2009, pajak adalah kontribusi wajib kepada negara yang terutang oleh orang pribadi atau badan yang bersifat memaksa berdasarkan undang-undang, dengan tidak mendapatkan imbalan secara langsung dan digunakan untuk keperluan negara bagi sebesarbesarnya kemakmuran rakyat. Dari definisi tersebut, dapat disimpulkan bahwa pajak memiliki unsur-unsur:

1. Iuran dari rakyat kepada negara Yang berhak memungut pajak hanyalah negara. Iuran tersebut berupa uang (bukan barang).

2. Berdasarkan undang-undang Pajak dipungut berdasarkan atau dengan kekuatan undang-undang serta aturan pelaksanannya.

3. Tanpa jasa timbal atau kontraprestasi dari negara yang secara langsung dapat ditunjuk. Dalam pembayaran pajak tidak dapat ditunjukkan adanya kontraprestasi individual oleh pemerintah.

4. Digunakan untuk membiayai rumah tangga negara, yakni pengeluaranpengeluaran yang bermanfaat bagi masyarakat luas.

Menurut Mardiasmo (2009; 7), sistem pemungutan pajak dibagi menjadi 3 yaitu:

1. Official Assessment System, adalah suatu sistem pajak yang memberi wewenang kepada pemerintah (fiskus) untuk menentukan besarnya pajak yang terutang oleh Wajib Pajak. Ciri-cirinya:

a. Wewenang untuk menentukan besarnya pajak terutang ada pada fiskus.

b. Wajib Pajak bersifat pasif.

c. Utang pajak timbul setelah dikeluarkan surat ketetapan pajak oleh fiskus.

2. Self Assessment System, adalah suatu sistem pemungutan pajak yang memberi wewenang kepada Wajib Pajak untuk menentukan sendiri besarnya pajak yang terutang. Ciri-cirinya:

a. Wewenang untuk menentukan besarnya pajak terutang ada pada Wajib Pajak sendiri.

b. Wajib Pajak aktif, mulai dari menghitung, menyetor, dan melaporkan sendiri pajak yang terutang.

c. Fiskus tidak ikut campur dan hanya mengawasi.

3. Withholding System, adalah suatu sistem pemungutan pajak yang memberi wewenang kepada pihak ketiga (bukan fiskus dan bukan Wajib Pajak yang bersangkutan) untuk menentukan besarnya pajak yang terutang oleh Wajib Pajak. Ciri-cirinya: wewenang 
Dinamika Sosial Budaya, Vol 20, No. 2, Desember 2018, pp 106-119

p-ISSN: 1410-9859\& e-ISSN: 2580-8524

http://journals.usm.ac.id/index.php/jdsb

menentukan besarnya pajak yang terutang ada pada pihak ketiga, selain fiskus dan Wajib Pajak.

Hambatan terhadap pemungutan pajak menurut Mardiasmo (2009; 8) dapat dikelompokkan menjadi:

1. Perlawanan pasifMasyarakat enggan (pasif) membayar pajak, yang dapat disebabkan antara lain:

a. Perkembangan intelektual dan moral masyarakat.

b. Sistem perpajakan yang (mungkin) sulit dipahami masyarakat.

c. Sistem kontrol tidak dapat dilakukan atau dilaksanakan dengan baik.

2. Perlawanan aktif Perlawanan aktif meliputi semua usaha dan perbuatan yang secara langsung ditujukan kepada fiskus dengan tujuan untuk menghindari pajak. Bentuknya antara lain:

a. Tax avoidance, yaitu usaha meringankan beban pajak dengan tidak melanggar Undang-Undang.

b. Tax evasion, yaitu usaha meringankan pajak dengan cara melangar Undang- Undang (menggelapkan pajak).

\section{Efektivitas dan Kontribusi}

Efektivitas berasal dari kata efektif yang memiliki makna tercapainya suatukeberhasilan sesuai tujuan yang telah ditetapkan sebelumnya. Menurut Mahmudi dalam Giroth (2016), efektivitas digunakan untuk mengukur hubungan antara hasil pungutan suatu pajak dengan tujuan atau target yang telah ditetapkan. Efektivitas merupakan hubungan antara keluaran dengan tujuan atau sasaran yang harus dicapai. Dikatakan efektif apabila proses kegiatan mencapai tujuan dan sasaran akhir kebijakan (spending wisely). Semakin besar output yang dihasilkanterhadap pencapaian tujuan dan sasaran yang ditentukan, maka semakin efektif proses kerja suatu unit organisasi.

Kontribusi dalam KBBI berarti sumbangan. Sumbangan dalam arti ini bisa diberi makna sebagai apa yang bisa diberikan secara nyata, umumnya kepada bangsa dan negara. Berikut adalah pengertian kontribusi menurut para ahli: Dany H. (2006) dalam pemahamannya, definisi kontribusi adalah suatu bentuk sumbangan berupa material (uang) yang bisa sokongan atau sumbangan.Yandianto (2000) makna kontribusi adalah kumpulan adanya uang iuran yang di dapatkan dari anggota atau masyarkat yang bentuknya sumbangan.Dengan demikian pengertian kontribusi ditarik kesimpulan bahwa kontribusi adalah sumbangan, sokongan atau dukungan terhadap sesuatu kegiatan.

\section{Penagihan Pajak}

Menurut Undang-undang Nomor 19 Tahun 2000 definisi penagihan pajak adalah serangkaian tindakan yang dilakukan oleh DJP agar penanggung pajak melunasi utang pajak dan biaya penagihan pajak dengan menegur/ memperingatkan, melaksanakan penagihan seketika dan sekaligus, memberitahukan surat paksa, mengusulkan pencegahan, melaksanakan penyitaan, melaksanakan penyanderaan, menjual barang yang telah disita.

Dasar hukum pelaksanaan penagihan pajak diatur dalam Undang-Undang Nomor 19 Tahun 1997 tentang Penagihan Pajak dengan Surat Paksa sebagaimana telah diubah dengan Undang-Undang Nomor 19 Tahun 2000 (selanjutnya disebut UU PPSP), Undang-Undang Nomor 6 Tahun 1983 
Dinamika Sosial Budaya, Vol 20, No. 2, Desember 2018, pp 106-119

p-ISSN: 1410-9859\& e-ISSN: 2580-8524

http://journals.usm.ac.id/index.php/jdsb

tentang Ketentuan Umum dan Tata Cara

Perpajakan sebagaimana telah beberapa kali diubah terakhir dengan Undang-Undang

Nomor 16 Tahun 2009 (selanjutnya disebut UU KUP), UndangUndang Nomor

8 Tahun 1985 tentang Pajak Bumi dan Bangunan sebagaimana telah diubah dengan Undang-Undang Nomor 12 Tahun 1994 (selanjutnya disebut UU PBB), dan Peraturan Pemerintah Nomor 74 Tahun 2011 tentang Tata Cara Pelaksanaan Hak dan Kewajiban Perpajakan (selanjutnya disebut PP-74/2011).

$$
\text { Berdasarkan Peraturan Menteri }
$$

Keuangan No. 24/PMK.03/2008 tahapan atau proses penagihan pajak adalah sebagai berikut:

1. Pejabat menerbitkan Surat Teguran, Surat Peringatan, ataupun surat lainnya yang sejenis apabila dalam jangka waktu 7 hari setelah jatuh tempo penanggung pajak tidak atau belum melunasi utang pajaknya.

2. Setelah itu apabila dalam jangka waktu 21 hari sejak diterbitkannya Surat Teguran, Surat Peringatan, atau surat lain yang sejenis diterima oleh penanggung pajak namun penanggung pajak masih belum juga melunasi utang pajaknya maka akan diterbitkan Surat Paksa.

3. Selanjutnya apabila Surat Paksa telah diterbitkan dan telah diterima oleh Penangggung Pajak tetapi dalam jangka waktu 2x24 jam masih belum melunasi utang pajaknya, maka pejabat dapat menerbitkan Surat Perintah Melaksanakan Penyitaan (SPMP).

4. Setelah itu apabila dalam jangka waktu 14 hari setelah dilakukannya penagihan pajak dengan Surat Perintah

\begin{abstract}
Melaksanakan Penyitaan (SPMP), ternyata penanggung pajak belum juga melunasi utang pajaknya, maka pejabat menerbitkan surat perintah tentang pengumuman lelang.
\end{abstract}

5. Pejabat dapat melaksanakan penjualan barang sitaan penanggung pajak melalui Kantor Lelang Negara apabila setelah diterbitkannya suratperintah tentang pengumuman lelang tetapi penanggung pajak masih belum juga melunasi utang pajaknya.

\section{Penelitian Terdahulu}

Penelitian mengenai efektivitas penagihan pajak dengan Surat Teguran, Surat Paksa dan Penyitaan dan kontribusinya terhadap penerimaan pajak mendapatkan hasil yang berbeda-beda. Hasil dari penelitian Rifqiansyah dkk. (2014), penagihan pajak aktif dengan surat teguran dinyatakan tidak efektif, dengan surat paksa dinyatakan kurang efektif, dan dengan penyitaan dinyatakan sudah efektif. Tingkat kontribusi penagihan pajak aktif melalui surat teguran, surat paksa maupun surat perintah melaksanakan penyitaan kurang dapat berkontribusi terhadap penerimaan pajak. Penelitian yang dilakukan oleh Destriyatna dkk. (2014) diperoleh hasil penagihan pajak yang dilakukan dengan surat teguran tidak efektif, dengan surat paksa tergolong cukup efektif, dan dengan penyitaan tergolong sangat tidak efektif dengan kontribusi ketiganya sangat kurang.

Hasil pengujian yang dilakukan oleh Madjid dan Kalangi (2015) menunjukan penagihan pajak dengan surat teguran dan surat paksa tergolong tidak efektif dan memberikan kontribusi yang sangat kurang terhadap penerimaan pajak penghasilan. 
Dinamika Sosial Budaya, Vol 20, No. 2, Desember 2018, pp 106-119

p-ISSN: 1410-9859\& e-ISSN: 2580-8524

http://journals.usm.ac.id/index.php/jdsb

\begin{abstract}
Penelitian Purnawardhani dkk. (2015)
mengenai penagihan pajak dengan surat teguran dan surat paksa diperoleh hasil yang tidak efektif dengan kontribusi yang sangat kurang terhadap penerimaan pajak secara keseluruhan. Dalam penelitian yang dilakukan Arief dkk. (2015), efektivitas penagihan pajak dengan surat paksa dapat dikategorikan kurang efektif dan tidak efektif. Kontribusi penagihan pajak dengan surat paksa terhadap penerimaan pajak memperlihatkan bahwa kontribusi yang diberikan dari realisasi penagihan pajak dengan menggunakan surat paksa tergolong rendah. Sedangkan hasil daripenelitian Kurniasari dkk. (2016) menunjukkan bahwa penerapan penagihan pajak dengan surat teguran dan surat paksa terbukti cukup efektif dengan kontribusi yang sangat kurang.
\end{abstract}

\section{METODE PENELITIAN}

\section{Jenis Penelitian}

Penelitian ini bertujuan untuk mengetahui gambaran penagihan pajak aktif di KPP Pratama Semarang Tengah Satu, yang meliputi tingkat efektivitas melalui penerbitan Surat Teguran, Surat Paksa dan Penyitaan, serta kontribusinya dalam mengoptimalkan penerimaan pajak. Sesuai dengan rumusan masalah dan tujuan penelitian yang ditetapkan, jenis penelitian yang digunakan adalah penelitian deskriptif. Tujuan dari penelitian deskriptif adalah menggambarkan dan menjelaskan tentang suatu fenomena, di mana fenomena tersebut dapat berupa karakteristik, bentuk, aktivitas suatu fenomena (Sukmadinata dalam Purnawardhani, 2015; 4).

\section{Objek Penelitian}

Penelitian ini dilakukan di Kantor Pelayanan Pajak Pratama Semarang Tengah Satu. KPP Pratama Semarang Tengah Satu merupakan instansi vertikal Direktorat Jenderal Pajak yang bertanggung jawab langsung kepada Direktorat Jenderal Pajak Kantor Wilayah Jawa Tengah I. KPP Pratama Semarang Tengah Satu berlokasi di Jalan Pemuda No. 2 Semarang. Telepon. 0243520211/3584536, faksimile 024$3520211 / 3584536$, kode pos 50138.

\section{Jenis dan Sumber Data}

Jenis data yang digunakan dalam penelitian ini terdiri dari:

1. Data Kualitatif Data yang berupa data verbal atau keterangan, seperti sejarah singkat instansi, struktur organisasi beserta pembagian tugas, Undang-Undang No.19 tahun

1997 sebagaimana telah dirubah terakhir Undang-undang No.19 Tahun 2000 tentang penagihan pajak dengan surat paksa, Keputusan Menteri Keuangan, Peraturan menteri Keuangan, dan data lain yang relevan dengan objek penulisan.

2. Data Kuantitatif Data yang berupa angkaangka seperti, jumlah penerbitan Surat Teguran, Surat Paksa, Surat Perintah Melaksanakan Penyitaan dan pencairan tunggakan, serta data lainnya yang dibutuhkan dalam rangka penulisan Penelitian ini. Sumber data yang digunakan dalam penelitian ini terdiri dari:

1. Data Primer Merupakan data yang diperoleh secara langsung dari instansi melalui hasil pengamatan dan wawancara dengan karyawan di Seksi Penagihan Seksi dan Seksi Pengolahan Data dan Informasi pada instansi tersebut.

2. Data SekunderMerupakan data yang diperoleh dari sumber di luar instansi dalam bentuk literatur-literatur akuntansi maupun informasi lain yang berhubungan dengan penulisan penelitian ini.

Metode Pengumpulan Data 
Dinamika Sosial Budaya, Vol 20, No. 2, Desember 2018, pp 106-119

p-ISSN: 1410-9859\& e-ISSN: 2580-8524

http://journals.usm.ac.id/index.php/jdsb

\section{Studi Pustaka}

Dalam metode ini penulis mempelajari dan mengumpulkan literatur seperti Undang-Undang Perpajakan, Peraturan Pemerintah, Keputusan Menteri Keuangan, Keputusan Dirjen Pajak, Surat Edaran Dirjen Pajak, dan peraturan pelaksanaan lainnya, serta buku-buku literatur lainnya sehingga dapat digunakan penulis untuk memperoleh pengetahuan dasar, teori dan bahan-bahan yang akan digunakan sebagai landasan teori penelitian dan acuan analisis permasalahan yang dibahas.

\section{Studi Lapangan (field search)}

Penelitian ini dilakukan terhadap kegiatan dari seluruh objek penelitian yang meliputi:

a. Metode Observasi atau Pengamatan

1) Yaitu dengan mengadakan pengamatan dan pengumpulan data secara langsung ke lapangan untuk memperoleh data yang berkaitan dengan pelaksanaan penagihan pajak oleh Jurusita Pajak di KPP Pratama Semarang Tengah Satu.

2) Membandingkan fakta-fakta dengan di lapangan dengan teori.

b. Metode Interview atau WawancaraPenulis mengumpulkan data dengan cara melakukan wawancara langsungdengan Fiskus di KPP Pratama Semarang Tengah Satu dan Jurusita sertapihak-pihak terkait pada Seksi Penagihan dan Seksi Pengolahan Data danInformasi

c. Dokumentasi

Dokumentasi yaitu mengumpulkan bahanbahan yang tertulis berupa datayang diperoleh dari perpustakaan maupun dari KPP Pratama SemarangTengah Satu yaitu data laporan realisasi penerbitan Surat Teguran, SuratPaksa, Surat Perintah
Melaksanakan Penyitaan dan Pencairan Tunggakan.

\section{Metode Analisis}

Untuk mengetahui gambaran penagihan pajak aktif di KPP Pratama Semarang Tengah Satu, metode yang digunakan dalam penelitian ini adalah metode analisis deskriptif rasio efektivitas dan rasio kontribusi (Handayaningrat dalam Purnawardhani, 2015; 4).Dengan metode ini, penulis menggambarkan efektivitas dan kontribusi penerbitan surat paksa terhadap pencairan tunggakan pajak berdasarkan data yang dikumpulkan berupa data mengenai Surat Teguran, Surat Paksa, dan Surat Perintah Melaksanakan Penyitaan yang terbit pada tahun 2015 dan 2016.

\section{Efektivitas}

Efektivitas merupakan hubungan antara keluaran dengan tujuan atau sasaran yang harus dicapai dalam kegiatan operasional, dikatakan efektif apabila suatu proses kegiatan mencapai tujuan dan akhir kebijakan (Mardiasmo, 2004:132). Rasio efektivitas penerbitan Surat Teguran, Surat Paksa, dan Surat Perintah Melaksanakan Penyitaan dihitung dengan menggunakan rumus:

Efektivitas $=\frac{\text { Jumlah penagihan yang dibayar }}{\text { Jumlah penagihan yang diterbitkan }} \times 100 \%$

Setelah itu barulah diukur dengan skala tingkat efektivitas dengan indikator sebagai berikut:

1. Persentase $<60 \%$ (Tidak Efektif)

2. Persentase $60 \%$ - $80 \%$ (Kurang Efektif)

3. Persentase $80 \%-90 \%$ (Cukup efektif)

4. Persentase $90 \%$ - $100 \%$ (Efektif)

5. Persentase $>100 \%$ (Sangat Efektif)

\section{Kontribusi}


Dinamika Sosial Budaya, Vol 20, No. 2, Desember 2018, pp 106-119

p-ISSN: 1410-9859\& e-ISSN: 2580-8524

http://journals.usm.ac.id/index.php/jdsb

Guna mengukur besarnya kontribusi penerimaan pajak yang berasal daripenerimaan tunggakan pajak dalam mengoptimalkan penerimaan pajak di KPPPratama Semarang Tengah Satu diperlukan sebuah analisis Rasio PenerimaanTunggakan Pajak (RPTP). Rumus yang digunakan dalam menganalisis RPTPmenurut Halim dalam Purnawardhani (2015; 3) adalah sebagai berikut:

$R P T P=\frac{\text { Realisasi penerimaan tunggakan pajak }}{\text { Penerimaan Pajak }} \times 100 \%$

Setelah menghitung menggunakan rumus RPTP, maka langkah selanjutnya adalah menganalisis dan menentukan klasifikasi kriteria kontribusi. Berikut klasifikasi kriteria kontribusinya:

1. Persentase $0-10 \%$ (Sangat Kurang)

2. Persentase $10-20 \%$ (Kurang)

3. Persentase $20-30 \%$ (Sedang)

4. Persentase 30 - 40\% (Cukup Baik)5.

Persentase 40 - 50\% (Baik)

6. Persentase diatas 50\% (Sangat Baik)

\section{Teknik Analisis Data}

Teknik analisis data dalam penelitian ini adalah sebagai berikut:

1. Menyajikan data tentang rancangan penerimaan pajak dan realisasi penerimaan pajak selama tahun 2015-2016.

2. Mengklasifikasikan laporan tindakan penagihan pajak berdasarkan jumlah penerbitan Surat Paksa, Surat Teguran, dan Penyitaan selama tahun 2015-2016 dan nominal tunggakan pajak, serta jumlah pelunasan tunggakanpajak yang disebabkan Surat Paksa, Surat Teguran dan Penyitaan.

3. Menghitung pengukuran tingkat efektivitas penagihan pajak dengan Surat Paksa, Surat Teguran dan Penyitaan selama periode 2015-2016 terhadap pencairan tunggakan pajak tahun 2015-2016.
4. Menghitung pengukuran kontribus pencairan tunggakan pajak yang berasal dari Surat Paksa, Surat Teguran dan Penyitaan terhadap penerimaan pajak tahun 20152016.

5. Mencari informasi mengenai faktor-faktor yang menjadi kendala dalam upaya penagihan pajak di KPP Pratama Semarang Tengah Satu dengan wawancara.

\section{PEMBAHASAN}

\section{Efektivitas Penagihan Pajak melalui Surat Teguran}

Seperti yang telah dijelaskan bahwa penagihan pajak aktif dengan Surat Teguran dapat dikatakan efektif jika mencapai angka $90 \%$. Namun, penerbitan Surat Teguran oleh KPP Pratama Semarang Tengah Satu termasuk dalam kriteria tidak efektif karena hasil perhitungan tingkat efektivitas masih di bawah 60\%. KPP Pratama Semarang Tengah Satu telah menerbitkan Surat Teguran dengan nilai penagihan pada tahun 2015 sebesar Rp 26.958.198.292 dan pada tahun 2016 sebesar Rp 29.024.833.282. Namun yang dapat direalisasikan hanya sebagian kecil dari target tersebut dengan jumlah penagihan yang dibayar pada tahun 2015 sebesar Rp 4.438.757.607 dan pada tahun 2016 sebesar Rp 3.296.729.459. Sehingga tingkat efektivitas penagihan pajak aktif dengan penerbitan Surat Teguran pada tahun 2015 mencapai persentase hanya sebesar 16,47\% dan tahun 2016 sebesar $11,36 \%$, dimana keduanya tergolong dalam kriteria tidak efektif.

Hasil ini sejalan dengan penelitian yang dilakukan oleh Rifqiansyah dkk.(2014), Destriyatna dkk. (2014), Madjid dan Kalangi (2015), serta Purnawardhanidkk. (2015) yang menyatakan bahwa penagihan pajak aktif yang dilakukan melalui Surat Teguran tergolong tidak 
Dinamika Sosial Budaya, Vol 20, No. 2, Desember 2018, pp 106-119

p-ISSN: 1410-9859\& e-ISSN: 2580-8524

http://journals.usm.ac.id/index.php/jdsb

efektif. Berdasarkan hasil wawancara yang dilakukan terhadap Juru Sita Pajak KPP Pratama Semarang Tengah Satu, hal ini disebabkan oleh beberapa faktor yaitu:

1. Wajib Pajak pindah alamat dan tidak dapat ditemukan keberadaannya, sehingga Surat Teguran kembali ke KPP Pratama Semarang Tengah Satu.

2. Wajib Pajak yang sudah tidak aktif/bubar usahanya.

3. Wajib Pajak sudah meninggal dan ahli waris tidak bersedia menanggungkewajiban perpajakannya.

4. Penanggung Pajak mengajukan permohonan angsuran atau penundaanpembayaran utang pajak5. Wajib Pajak tidak mempunyai kemampuan bayar lagi.

\section{Efektivitas Penagihan Pajak melalui Surat Paksa}

Seperti yang telah dijelaskan bahwa penagihan pajak aktif dengan Surat Paksa dapat dikatakan efektif jika mencapai angka $90 \%$. Namun, penerbitan Surat Paksa oleh KPP Pratama Semarang Tengah Satu belum dapat dikatakan efektifkarena hasil perhitungan tingkat efektivitas yang belum mencapai persentase tersebut. KPP Pratama Semarang Tengah Satu telah menerbitkan Surat Paksa kepada Wajib Pajak dengan nilai penagihan pada tahun 2015 sebesar Rp 22.962.675.217 dan pada tahun 2016 sebesar Rp 22.686.904.588. Namun yang dapat direalisasikan hanya sebagian dari target tersebut dengan jumlah penagihan yang dibayar pada tahun 2015 sebesar Rp 1.199.275.108 dan pada tahun 2016 sebesar Rp 256.131.089. Sehingga tingkatefektivitas penagihan pajak aktif dengan penerbitan Surat Paksa pada tahun 2015 sebesar 5,22\% dan tahun 2016 sebesar 1,13\%, dimana keduanya tergolong dalam kriteria tidak efektif.
Hasil ini sejalan dengan penelitian yang dilakukan oleh Madjid dan Kalangi (2015), Purnawardhani (2015), serta Arief dkk. (2015) yang menyatakan bahwa penagihan pajak aktif yang dilakukan melalui Surat Paksa tergolong tidak efektif. Berdasarkan hasil wawancara yang dilakukan terhadap Juru Sita Pajak KPP Pratama Semarang Tengah Satu, hal ini disebabkan oleh beberapa faktor yaitu:

1. Wajib Pajak pindah alamat dan tidak dapat ditemukan keberadaannya, sehingga Surat Paksa kembali ke KPP Pratama Semarang Tengah Satu.

2. Wajib Pajak yang sudah tidak aktif/bubar usahanya.

3. Penanggung Pajak tidak mengakui memiliki utang pajak.

4. Wajib Pajak tidak mempunyai kemampuan bayar lagi.

\section{Efektivitas Penagihan Pajak melalui Penyitaan}

KPP Pratama Semarang Tengah Satu telah menerbitkan Surat PerintahMelaksanakan Penyitaan kepada Wajib Pajak dengan nilai penagihan pada tahun2015 sebesar Rp 15.066.268.201 dan pada tahun 2016 sebesar Rp 16.885.520.967.Jumlah penagihan yang dapat direalisasikan dari target tersebut pada tahun 2015sebesar Rp 18.189.982.175 dan pada tahun 2016 sebesar Rp 12.797.076.596.Sehingga tingkat efektivitas penagihan pajak aktif dengan penerbitan SuratPerintah Melaksanakan Penyitaan pada tahun 2015 sebesar $120,73 \%$ tergolong sangat efektif karena melebihi angka 100\% dan pada tahun 2016 sebesar $75,79 \%$ sehingga tergolong kurang efektif.

Hasil ini sejalan dengan penelitian yang dilakukan oleh Rifqiansyah dkk. (2014) yang menyatakan bahwa penagihan pajak aktif yang dilakukan melalui Penyitaan tergolong sudah 
Dinamika Sosial Budaya, Vol 20, No. 2, Desember 2018, pp 106-119

p-ISSN: 1410-9859\& e-ISSN: 2580-8524

http://journals.usm.ac.id/index.php/jdsb

efektif meskipun di tahun 2016 tergolong

kurang efektif. Berdasarkan hasil wawancara yang dilakukan terhadap Juru Sita Pajak KPP

Pratama Semarang Tengah Satu, pencapaian realisasi pencairan tunggakan pajak melalui Penyitaan dapat melebihi $75 \%$ karena Wajib Pajak bersikap kooperatif saat dilakukan Penyitaan. Dalam beberapa kasus, Wajib Pajak juga menolak penyitaan atas asetnya dan lebih memilih melunasi utang pajaknya setelah disampaiakan Surat Perintah Melaksanakan Penyitaan oleh Juru Sita Pajak KPP Pratama Semarang Tengah Satu.

\section{Kontribusi Penerimaan Pajak melalui Surat} Teguran

Sebagaimana tertera pada tabel 5.7, pada tahun 2015 diperoleh kontribusi penerimaan pajak melalui penerbitan Surat Teguran sebesar $1,21 \%$ dan tergolong dalam kriteria sangat kurang. Pada tahun 2016, diperoleh kontribusi penerimaan pajak melalui penerbitan Surat Teguran sebesar $0,62 \%$ dan tergolong dalam kriteria sangat kurang. Hal tersebut disebabkan karena jumlah pencairantunggakan pajak oleh Wajib Pajak melalui Surat Teguran tidak terlalu besar, sehingga hasil pencairan tunggakan atas penerbitan Surat Teguran tidak sebanding dan tidak memiliki kontribusi yang cukup besar terhadap penerimaan pajak di KPP Pratama Semarang Tengah Satu. Menyadari bahwa masih banyak tunggakan yang belum mampu dicairkan dengan surat teguran, maka perlu adanya evaluasi agar dapat dilakukan perbaikan-perbaikan khususnya di bidang penagihan sehingga diharapkan mampu meningkatkan kontribusi penagihan pajak aktif melalui Surat Teguran di KPP Pratama Semarang Tengah Satu misalnya dengan melakukan penelitian administrasi lebih intensif terhadap Wajib Pajak yang tidak dapat ditemukan lagi dengan mencari data informasi keberadaan Wajib Pajak melalui tetangga atau saudara Wajib Pajak.

\section{Kontribusi Penerimaan Pajak melalui Surat Paksa}

Pada tabel 5.8, pada tahun 2015 diperoleh kontribusi penerimaan pajak melalui penerbitan Surat Paksa sebesar $0,33 \%$ dan tergolong dalam kriteria sangat kurang. Pada tahun 2016, diperoleh kontribusi penerimaan pajak melalui penerbitan Surat Paksa sebesar 0,05\% dan tergolong dalam kriteria sangat kurang. Hal tersebut disebabkan karena jumlah pencairan tunggakan pajak oleh Wajib Pajak melalui Surat Paksa tidak terlalu besar, sehingga hasil pencairan tunggakanatas penerbitan Surat Paksa tidak sebanding dan tidak memiliki kontribusi yang cukup besar terhadap penerimaan pajak di KPP Pratama Semarang Tengah Satu.

Menyadari bahwa kontribusi surat paksa masih sangat kurang, pihak KPP Pratama Semarang Tengah Satu perlu mengadakan evaluasi agar dapat dilakukan perbaikan-perbaikan kinerja di bidang penagihan serta melakukan upaya-upaya yang dapat meningkatkan kesadaran penanggung pajak sehingga dapat memperbesar jumlah pencairan tunggakan pajak melalui Surat Paksa dan memaksimalkan kontribusi terhadap penerimaan pajak di KPP Pratama Semarang Tengah Satu misalnya dengan membuat surat himbauan dan konseling terhadap Wajib Pajak yang menunggak pajak secara bertahap.

\section{Kontribusi Penerimaan Pajak melalui Penyitaan}

Sebagaimana tertera pada tabel 5.9, pada tahun 2015 diperoleh kontribusi penerimaan pajak melalui penerbitan Surat Perintah Melaksanakan Penyitaan sebesar 4,94\% dan tergolong dalam kriteria sangat kurang. Pada tahun 2016, diperoleh kontribusi penerimaan pajak melalui penerbitan Surat 
Dinamika Sosial Budaya, Vol 20, No. 2, Desember 2018, pp 106-119

p-ISSN: 1410-9859\& e-ISSN: 2580-8524

http://journals.usm.ac.id/index.php/jdsb

Perintah Melaksanakan Penyitaan sebesar 2,42\% dan tergolong dalam kriteria sangat kurang. Hal tersebut disebabkan karena jumlah pencairan tunggakan pajak oleh Wajib Pajak melaluiPenyitaan tidak terlalu besar, sehingga hasil pencairan tunggakan atas penerbitan Surat Perintah Melaksanakan Penyitaan tidak sebanding dan tidak memiliki kontribusi yang cukup besar terhadap penerimaan pajak di KPP Pratama Semarang Tengah Satu. Menyadari bahwa masih terdapat tunggakan yangbelum mampu dicairkan dengan Surat Perintah Melaksanakan Penyitaan, maka perlu adanya evaluasi agar dapat dilakukan perbaikan-perbaikan khususnya di bidang penagihan sehingga mampu meningkatkan kontribusi penagihan pajak aktif melalui Penyitaan di KPP Pratama Semarang Tengah Satu misalnya dengan memaksimalkan penagihan aktif berupa pemblokiran, pencegahan dan penyanderaan terhadap Wajib Pajak besar yang tidak mempunyai itikad baik dalam melunasi tunggakan pajaknya.

\section{KESIMPULAN}

Kesimpulan yang dapat diambil dari penelitian ini adalah:

1. Realisasi penerimaan pajak di KPP Pratama Semarang Tengah Satu belum mencapai target yang telah ditetapkan dengan adanya tunggakan pajak sebesar Rp 14.332.979.964 pada tahun 2015. Pada tahun 2016, realisasi penerimaan pajak KPP Pratama Semarang Tengah Satu adalah sebesar Rp 528.825.764.900 dan telah melewati target yang ditetapkan yaitu sebesar $\mathrm{Rp}$ 503.854.475.000 sehingga tidak terdapat tunggakan pajak.

2. Tingkat efektivitas penagihan pajak aktif dengan Surat Teguran pada tahun 2015 dan 2016 adalah 16,47\% dan 11,36\%. Hasil tersebut menunjukkan bahwa penagihan pajak aktif dengan penerbitan Surat Teguran tidak efektif.

3. Tingkat efektivitas penagihan pajak aktif dengan Surat Paksa pada tahun 2015 dan 2016 adalah 5,22\% dan 1,13\%. Hasil tersebut menunjukkan bahwa penagihan pajak aktif dengan penerbitan Surat Paksa tidak efektif.

4. Tingkat efektivitas penagihan pajak aktif dengan Penyitaan pada tahun 2015 dan 2016 adalah $120,73 \%$ dan $75,79 \%$. Hasil tersebut menunjukkan bahwa penagihan pajak aktif dengan Penyitaan di tahun 2015 sangat efektif dan di tahun 2016 kurang efektif.

5. Pada tahun 2015 diperoleh kontribusi penerimaan pajak melalui penerbitan Surat Teguran sebesar $1,21 \%$ dan tergolong dalam kriteria sangat kurang. Pada tahun 2016 diperoleh kontribusi penerimaan pajak melalui penerbitan Surat Teguran sebesar $0,62 \%$ dan tergolong dalam kriteria sangat kurang.

6. Pada tahun 2015 diperoleh kontribusi penerimaan pajak melalui penerbitan Surat Paksa sebesar $0,33 \%$ dan tergolong dalam kriteria sangat kurang. Pada tahun 2016 diperoleh kontribusi penerimaan pajak melalui penerbitan Surat Paksa sebesar $0,05 \%$ dan tergolong dalam kriteria sangat kurang.

7. Pada tahun 2015 diperoleh kontribusi penerimaan pajak melalui Penyitaan sebesar 4,94\% dan tergolong dalam kriteria sangat kurang. Pada tahun 2016 diperoleh kontribusi penerimaan pajak melalui Penyitaan sebesar $2,42 \%$ dan tergolong dalam kriteria sangat kurang

\section{Saran}

Berdasarkan hasil penelitian yang dilakukan, pelaksanaan penagihan pajak melaluiSurat Teguran 
Dinamika Sosial Budaya, Vol 20, No. 2, Desember 2018, pp 106-119 p-ISSN: 1410-9859\& e-ISSN: 2580-8524

http://journals.usm.ac.id/index.php/jdsb

Surat Paksa, dan Penyitaan di KPP Pratama

Semarang Tengah masih belum efektif. Saran yang diberikan dalam penelitian ini adalah:

1. Untuk menunjang keberhasilan pencairan piutang pajak, Juru Sita Pajak sebaiknya mengetahui karakteristik masing-masing Wajib Pajak terlebih dahulu, karena kondisi dan karakteristik Wajib Pajak satu dengan yang lain berbeda.

2. Perlu dilakukan profilling terhadap 100 penunggak pajak terbesar dan melakukan pengawasan prioritas terhadap Wajib Pajak tersebut3. Ketersediaan data dan informasi yang lengkap dan akurat sangat diperlukan dalam proses penagihan pajak, sehingga Juru Sita Pajak perlu dibekali berbagai teknik pencarian data.

\section{DAFTAR PUSTAKA}

Anggraini, Devi Septya dkk. 2016. "Efektivitas Pelaksanaan Pemeriksaan Pajak Dalam Rangka Meningkatkan Penerimaan Pajak (Studi Pada Kantor Pelayanan Pajak Pratama Malang Selatan).” Jurnal Perpajakan (JEJAK), Volume 8, Nomor 1.

Arief, Revvica Firmannisya dkk. 2015. "Analisis Efektivitas Penagihan Pajak Dengan Surat Paksa Dalam Meningkatkan Penerimaan Pajak (Studi Pada KPP Pratama Malang Selatan Tahun 2012-2014).” Jurnal Administrasi Bisnis - Perpajakan (JAB), Volume 6, Nomor 1. Data dari Kantor Pelayanan Pajak Pratama Semarang Tengah Satu.

Destriyatna, Gilang dkk. 2014. "Efektivitas Penagihan Pajak dengan Surat Teguran, Surat Paksa dan Penyitaan dalam Mengoptimalkan Penerimaan Pajak di Kantor Pelayanan Pajak Pratama Malang Selatan.” Jurnal

Perpajakan, Volume 3, Nomor 1, Desember.

Giroth, David dkk. 2016. “Analisis Efektivitas Pemeriksaan Pajak Dalam Upaya Meningkatkan Penerimaan Pajak Pada Kantor Pelayanan Pajak Pratama Manado." Jurnal Berkala Ilmiah Efisiensi, Volume 16, Nomor 04.

Halim, Abdul, Icuk Rangga Bawono, dan Amin Dara. 2014. Perpajakan: Konsep, Aplikasi, Contoh, dan Studi Kasus. Jakarta: Salemba Empat. Keputusan Direktorat Jenderal Pajak Nomor KEP-141/PJ/2007 tentang
"Penerapan Organisasi, Tata Kerja, dan Saat Mulai Beroperasinya Kantor Wilayah Direktorat Jenderal Pajak Jawa Tengah II dan Kantor Wilayah Direktorat Jenderal Pajak Daerah Istimewa Yogyakarta, Serta Kantor Pelayanan Pajak Pratama dan Kantor Pelayanan, Penyuluhan dan Konsultasi Perpajakan di Lingkungan Kantor Wilayah Direktorat Jenderal Pajak Jawa Tengah I, Kantor Wilayah Direktorat Jenderal Pajak Jawa Tengah II dan Kantor Wilayah Direktorat Jenderal Pajak Daerah Istimewa Yogyakarta".

Kurniasari, Putri dkk. 2016. "Efektivitas Penagihan Pajak Dengan Surat Teguran dan Surat Paksa Terhadap Penerimaan Pajak Pada Kantor Pelayanan Pajak (KPP) Pratama di Balikpapan." Jurnal Ekonomi dan Keuangan, Volume 13, Nomor 1.

Madjid, Olvi dan Lintje Kalangi. 2015. "Efektivitas Penagihan Pajak dengan Surat Teguran dan Surat Paksa Terhadap Penerimaan Pajak Penghasilan Pada Kantor Pelayanan Pajak Pratama Bitung." Jurnal EMBA 478, Volume 3, Nomor 4, Desember, halaman 478-487. Mardiasmo. 2009. Perpajakan: Edisi Revisi 2009.

Yogyakarta:Andi. Pedoman Penagihan Pajak. 2015. Jakarta: Direktorat Pemeriksaan dan Penagihan. Peraturan Menteri Keuangan Nomor 206.2/PMK.01/2014 tentang "Organisasi dan Tata Kerja Instansi Vertikal Direktorat Jenderal Pajak".

Purnawardhani, Restika dkk. 2015. "Efektivitas Penagihan Pajak Aktif Dengan Surat Teguran dan Surat Paksa Dalam Upaya Optimalisasi Penerimaaan Pajak (Studi Kasus Pada Kantor Pelayanan Pajak Madya Malang)." Jurnal Perpajakan (JEJAK), Volume 1, Nomor 1.

Rifqiansyah, Hasbi dkk. 2014. "Analisis Efektivitas dan Kontribusi Penagihan Pajak Aktif Terhadap Pencairan Tunggakan Pajak (Studi Pada Kantor Pelayanan Pajak Pratama Malang Utara)." Jurnal Administrasi Bisnis (JAB), Volume 15, Nomor 1, OktoberSaputra, Rachman Bawono Sidiq dkk. 2016. "Implementasi Penagihan Pajak Sesuai Undang-Undang Nomor 19 Tahun 1997 Jo. Undang-Undang Nomor 19 Tahun 2000 (Studi Pada Kantor Pelayanan Pajak Pratama Mojokerto)." Jurnal Perpajakan (JEJAK), Volume 8, Nomor 1.

Tambunan, Bonifasius H. 2016. "Efektivitas Penagihan Pajak Penghasilan Pasal 21 Terhadap Penerimaan Pajak Melalui Surat Paksa (Studi Kasus Pada Kantor Pelayanan Pajak Pratama (KPP) Medan Petisah.” Jurnal Akuntansi dan Bisnis, Volume 2, Nomor 2, Nopember. 
Dinamika Sosial Budaya, Vol 20, No. 2, Desember 2018, pp 106-119 p-ISSN: 1410-9859\& e-ISSN: 2580-8524

http://journals.usm.ac.id/index.php/jdsb

Susunan Dalam Satu Naskah Undang-Undang Perpajakan. 2013. Jakarta: Direktorat Penyuluhan, Pelayanan, dan Hubungan Masyarakat. Undang-undang Nomor 19 Tahun 1997 tentang "Penagihan Pajak dengan Surat Paksa" sebagaimana telah diubah dengan Undang-undang Nomor 19 Tahun 2000. 